\title{
ANALYSIS OF IMPLEMENTATION SAK CONVERGED IFRS FOR FINANCIAL INSTRUMENTS (PSAK 50, 55 AND 60) IN BANKING COMPANY
}

\author{
Elly Astuti ${ }^{1}$ \\ Nur Wahyuning Sulistyowati² \\ ${ }^{1}$ Pendidikan Akuntansi Universitas PGRI Madiun \\ ${ }^{2}$ Pendidikan Akuntansi Universitas PGRI Madiun \\ elly2191@gmail.com
}

\begin{abstract}
IFRS is a set of global accounting regulations. IFRS uses a fair value accounting basis that provides a different perspective from previous standards based on historical cost. The use of fair value is considered to make the financial statements more transparent. Excess fair value accounting for historical cost has been accepted by the public which includes professional accountants and standard makers in various countries. Nevertheless, the fair value accounting of the historical cost is predominantly based on countries with efficient market conditions with good financial reporting environment.

Indonesia is one of the developing countries that decided to converge IFRS with its main concept of fair value accounting as a commitment to enter G20 member countries. In 2011 all the necessary infrastructure in the context of convergence to IFRS is already at the completion stage. In 2012 began to be implemented in stages. In 2015 the adaptation process has entered the second period. However, there is still little research to reveal the extent to which the implementation of IFRS convergence in the process of preparing the company's financial statements and its impact on its financial statements. Therefore, in this research will reveal the level of convergence of IFRS primarily the concept of fair value accounting for financial instruments (as contained in PSAK 50, 55 and 60) in practice primarily in banking sector companies.

This research is a descriptive qualitative research with triangulation technique. The results show that $P T$. Bank Negara Indonesia (Persero) Tbk has implemented IFRS converged PSAK for financial instruments (PSAK 50, 55, and 60) in accordance with the adaptation stage. Even companies have volunteered to make early adoptions before the effective date is enacted. In the comparative analysis of financial statements presented from 2009 to 2015, it was found that the application of IFRS converged IFRS has a positive impact on users of financial statements because the information presented is complete and informative so that no mistakes are expected in the process of making economic decisions.
\end{abstract}

Keywords; Fair value accounting, IFRS convergence, financial instrument, a banking company. 


\section{INTRODUCTION}

Indonesia has decided to adopt international accounting standards as a form of commitment of G-20 member countries. International accounting standards (hereinafter referred to as IFRS) have been gradually adopted since 2008. In 2012, Indonesia has implemented the first full adoption phase and in 2015 has entered the second phase. In 2015 the gap between accounting standards in Indonesia (hereinafter referred to as PSAK) with IFRS is only 1 year. Implementation of this adaptation certainly affects the accounting practices in Indonesia especially the banking sector.

Banking is a business field with the main focus of collecting and channeling funds from the community. Therefore, the largest asset component of the bank is formed on accounts receivable and financing components are mostly formed from customer deposits (short-term debt). PSAK has regulated such components in PSAK 50 for presentation and disclosure, PSAK 55 for recognition and measurement, SFAS 68 for fair value measurement (PSAK 2015). The regulatory development process of financial instruments continues with the issuance of PSAK 71 on Financial Instruments and Its Implementation.

Continuous development of regulations is expected to further improve the quality of accounting information primarily for financial instruments in banking companies. The IAI as the board of developers of accounting standards in Indonesia also establishes cooperation with Bank Indonesia to publish accounting guidelines for Indonesian banking (PAPI) to adjust the progress of the existing PSAK and the elimination of banking accounting regulations in PSAK (PSAK 31: Banking Accounting is eliminated as of January 1, 2015). PAPI is an answer to the public concern over the accuracy of the determination of fair value of inactive financial instruments in the market so that it will be greatly influenced by management policies.

Landsman (2006) has proposed several constraints of determining fair value with the proposition of the information asymmetry theory as follows: "Managers have more information on better company conditions than others. For that in determining fair value, he will choose the most profitable model for measuring its financial instruments ". Correspondingly, Levin (2004) revealed that banking companies have a greater degree of information asymmetry than any other company. This is due to the absence of an active market for loans granted so that direct observation of credit quality cannot be implemented. In the event of a problematic credit, the bank can replace its risk composition by extending the customer's credit life.

A number of financial instruments held by banks and the many regulations governing the operations of banking companies, making the management mechanism are very complex. Therefore, research on the implementation of PSAK related to financial instruments and other banking regulation has not been done. This study aims to reveal how the practice of recognizing, measuring, presenting, and disclosing financial instruments and methods for measuring fair value by banking companies to expand the study of similar research literacy in the future.

\section{LITERATURE REVIEW}

\section{A. The concept of Fair Value Accounting}

The concept of fair value accounting was originally used to calculate the biological assets of cattle and livestock companies, assuming the assets in the business field are living creatures that continue to grow so that the use of 
historical cost is considered inadequate. In early 2003, the concept of fair value accounting began to be widely used by companies in Europe (Hardiani, 2014).

The increasingly dynamic business development, very fast and widespread, gave birth to a thought that the concept of historical cost is not relevant because it does not reflect market value. The use of historical cost is considered to result in an increasing gap between the concept of economic profit and accounting profit. To that end, the international accounting standards board (IASB) decided to adopt the concept of fair value accounting as the basis for measuring assets. DAKAK International stated that the application of fair value accounting is the most relevant concept in the business world (Epsteins and Jermakowic, 2010) used as the basis for the right decision.

Fair value is defined in IFRS (Handoko, 2010) as, "the amount for which an asset could be exchanged between knowledgeable, willing parties in an arm's length transaction." This fair value is used to measure:

1. One asset

2. A group of assets

3. One liability

4. A group of liabilities

5. The net consideration of one or more assets minus one or more related liabilities

6. A segment or division of an entity

7. One location or territory of an entity

8. One whole entity

Measurements referred to in this context are measurements after initial measurement, ie, financial reporting. From the definition, it can also be concluded that fair value measurements are made when assets (or liabilities can be exchanged, not when assets (or liabilities) are actually exchanged.the basis for fair value measurement can be done using the following approaches:

1. Market Approach.

In this approach, fair value is measured by market price or other relevant information resulting from transactions in the market. This includes the prices of similar assets (liabilities) that exist in the market and other valuation methods that are consistent with the market approach. The sequence used when the fair value using the market approach is, first, the market price of the asset (liability) at the time of reporting, if there is no asset market price (liability) then using the market price of a similar asset (liabilities) similarly using a model consistent with the market approach (eg matrix pricing model, etc.)

2. Income Approach

This approach uses assessment techniques to change future value (eg cash flow or profit) to its discounted value. The fair value measurement in this approach uses the basic values seen from current market expectations of the 
future value of assets (liabilities). This approach includes using present value, option pricing).

3. Cost approach

The cost approach is also called the current replacement cost approach. This substitute is the amount needed to replace an asset (Handoko, 2010).

However, the application of fair value accounting concept is still a debate in several countries. One example of such cases is the occurrence of the subprime mortgage crisis in the US indicated by some assessors as one of the impacts due to the implementation of fair value accounting.

\section{B. Weakness and Excellence Fair Value Accounting}

The weaknesses and advantages of fair value accounting are as follows:

1. Advantages

- Provide current more relevant financial information as the basis for decision making.

- Improve the transparency of financial statements.

- Improve the comparability of financial statements.

- Close the concept of economic profit with the concept of accounting profit, so the risk profile of an entity can be known well

2. Weakness

- The market value does not reflect fair value because market conditions are less active or inefficient.

- The fair value mechanism is based on a mark to market that will lead to continuous changes in the financial statements. This makes it difficult to ascertain whether the resulting profit/loss is caused by a business decision or due to a change in fair value.

- Fair value leads to differences in the company's management appraisal so that it will allow for earning management opportunities.

(Wibisana, 2009; Sukendar, 2012)

For that company that will apply fair value accounting should prepare some of the following:

a. Entities should seek to understand and explore fair value accounting itself.

b. Entities should prepare distance analysis (gap analysis) to understand what needs to be done to close the gap between existing practices and what to do in fair value implementation.

c. The entity shall prepare an information system that accommodates new standards that have applied the fair value.

d. Entities improve information technology systems to accommodate demand in fair value implementation.

e. Entities conduct trials with parallel runs until confidence is obtained that the new system is ready to go live. To ensure its success, the entity must have the full support of top management (there is the tone from the top). Entities 
may consider the use of consultant services to assist with the preparation of the adaptation process.

\section{Fair Value Accounting Adaptation in Indonesia}

Prior to the IFRS convergence, Indonesia used historical cost in measuring its transactions. Along with the rapid development of the business world, the historical cost concept is considered irrelevant. The assessment gave birth to a concept of ideas to adopt fair value accounting across all business sector lines. In addition, there is a view that the need for an internationally accepted form of standard, it is necessary to adapt this fair value accounting in all countries in order to improve the comparability of financial statements that can be used as the basis for the main economic decision making of investment.

Indonesia has committed to adopting all standards issued by IFRS that apply fair value according to market dynamics. The commitment was made to implement the Indonesian government agreement as a member of the G20 forum (Dewi, Almilia and Herlina, 2012). As the Financial Accounting Standards Board (DSAK) in Indonesia, IAI has developed all accounting standards based on the concept of fair value (Wibisana, 2009) which must be applied in Indonesia starting in 2012.

\section{Fair Value Accounting Regulation for Financial Instruments}

Fair value is the amount to be paid or received on items that are divisible between parties who are known to be willing to make transactions. The concept of fair value (hereinafter referred to as fair value) has actually been deregulated in PSAK 2007. However, in the definition of fair value in the year contains several weaknesses, so adjustments are required.

"Nilai wajar adalah nilai dimana suatu aset dipertukarkan atau suatu kewajiban dapat diselesaikan antara pihak yang memahami dan berkeinginan untuk melakukan transaksi wajar" (PSAK 50 paragraf 07 tahun 2007).

Based on these citations it is known that there is no specific explanation as to whether the assets exchanged are sold or purchased. At the next definition, there is no specific explanation regarding the settlement of the fair value because it does not appoint a creditor and does not specify when the transaction occurred.

In SFAS No. 55 Revision 2006 paragraphs 07-16 of 2007 describes the classification of financial instruments and then follows the regulation of hedging activities on financial instruments. In 2011 and resumed in 2014, PSAK is revised to conform to IAS 39. However, there is a criticism of this regulation that the new PSAK 71 is set to be effective for 2020.

PSAK 71 was issued to respond to criticisms of PSAK 55 which are not suitable in some respects as follows:

1. The classification of financial instruments based on IAS 39 is considered inconsistent. This occurs because the basis of classification is based on the intensity of management so that the same financial instruments but held by 
different entities will result in different measurements, assessments, and presentations in the financial statements.

2. The model of impairment is considered not in accordance with the condition/performance of the company.

3. The hedge accounting that is regulated in PSAK 55 is not in line with the risk management that the company has implemented.

On 26 November 2010 the IAI Standards Board approved PSAK 60 that regulates financial instruments and became effective on 1 January 2012. The PSAK 60 adopted IFRS 7 as of 1 January 2009. On 29 April 2014 SFAS 60 was revised for IFRS 7 as per January 1, 2013. The regulation establishes the mandatory disclosures that the company must provide on financial instruments to supersede the regulations laid down in PSAK 50 and PSAK 55. Based on Table 2 it is known that the regulation relating to the main financial instrument to perform the valuation of fair value, continuously develops. In 2017 DSAK IAI re-adapt the IFRS to produce an amendment and an annual adjustment of one of the PSAK 60 that regulates disclosure of financial instruments. Based on the table it is also known that in the period 2015 there was the addition of PSAK 68 which regulated the way of fair value measurement.

In PSAK 68 it is clear that the main focus of fair value measurement lies in assets and liabilities as it is the main subject of accounting measurement (PSAK 68 of 2015). Therefore, a fair value assessment of financial instruments in a banking company can be used as a benchmark for fair value accounting implementation after the IFRS adaptation period. At fair value measurement, PSAK 68 defines fair value as a price.

"Nilai wajar adalah harga yang akan diterima untuk menjual suatu aset atau harga yang akan dibayar untuk mengalihkan suatu liabilitas dalam transaksi teratur di pasar utama (atau pasar yang paling menguntungkan) pada tanggal pengukuran dalam kondisi pasar saat ini (yaitu harga keluar) terlepas apakah harga tersebut dapat diobservasi secara langsung atau diestimasi menggunakan teknik penilaian lain" (PSAK 68 paragraf 25 tahun 2015).

Based on these assumptions, the fair value measurement is implemented through several steps which are then described in paragraphs 72-90. The highest hierarchy of fair value determination is set for the quoted price (non-adjusted) ie the value of assets and liabilities based on identical instruments in the active market. The second hierarchy performs inputs other than quoted prices, ie the determination of fair value is based on observed on assets or liabilities either directly or indirectly. A third hierarchy is an input to unobservable assets and liabilities.

\section{RESEARCH METHODOLOGY}

This study is a comparative study that is comparing the regulation of financial instruments that are PSAK 50, 55 and 60 with implementation in banking companies. The object of research is PT. Bank Negara Indonesia in 2009 until 2014. The reason 
for the election of the year because the process of convergence IFRS hit the regulation of financial instruments changed in those years.

Data collection method used is documentation technique that is studying PSAK 2015 and company financial statement presented in the observation period. The analysis will be focused on the implementation of fair value accounting that has been implemented. The analysis is done in two stages:

1. Tracing the accounting policies set by the company.

2. Compare it with PSAK 50, 55 and 60

3. Conclusions drawing on the implementation of IFRS converged PSAK which has been implemented by the company.

\section{RESULT, ANALYSIS, AND DISCUSSION}

At the stage of the analysis that has been done found that banking companies have uniqueness with the many regulations that regulate strictly. In addition to IFRSaffiliated IFRS PSAKs, banking companies must also comply with Bank Indonesia regulations set forth in PAPI (Indonesian Banking Accounting Guidelines) and provisions of Indonesian banking authorities and Capital Market and Financial Institution Supervisory Agency (BAPEPAM-LK) Regulation no. VIII.G.7 on "Guidelines for Presentation of Financial Statements" attached in Attachment of Decision of Chairman of BAPEPAM-LK. KEP.06 / PM / 2000 dated March 13, 2000, and Circular Letter of BAPEPAM - LK no. SE-02 / BL / 2008 dated 31 January 2008 regarding "Guidelines on Presentation and Disclosure of Financial Statements of Issuers or Public Companies in the General Mining, Oil and Gas Industry and Banking Industry". For some banks that have opened branches, I also apply the regulations contained in PSAK Syariah and PAPSI. The tight regulations that bind the banking industry make it even more interesting to be analyzed primarily in the implementation of regulations on financial instruments.

The main regulatory developments of PSAK relating to financial instruments gradually revised and had a significant impact on corporate financial reporting. The analysis of the Company's financial statements from 2009 to 2015 shows some changes to the implementation of SFAS 50, 55 and 60 for financial instrument classification, reclassification provisions, fair value determination process, recognition of revenues and expenses on fair value, and hedging activities on changes fair value.

The classification of financial instruments in 2009 the company still uses PSAK 50 (revised 1999), PSAK 50 (revised 1999). In 2009 the classification of financial instruments included only "for trading", "available for sale" and "held to maturity". But the classification is not explained in detail about the basic criteria or the definition of a financial instrument in a certain classification. In 2010 the company decided to use PSAK 50 revised 2006 and PSAK 55 revised 2006. The changes made the company's financial statements more informative when compared to the previous period because the basis of classification and measurement of financial instruments has been described in detail. The classification of financial instruments in 2010 is as follows: 
- Aset keuangan yang diukur pada nilai wajar melalui laporan laba rugi, yang memiliki 2 (dua) sub-klasifikasi, yaitu aset keuangan yang ditetapkan demikian pada saat pengakuan awal dan aset keuangan yang diklasifikasikan dalam kelompok yang diperdagangkan;

- Kredit yang diberikan dan piutang;

- Investasi dimiliki hingga jatuh tempo;

- Investasi tersedia untuk dijual.
Kewajiban keuangan diklasifikasikan ke dalam kategori sebagai berikut pada saat pengakuan awal:

- Diukur pada nilai wajar melalui laporan laba rugi, yang memiliki 2 (dua) subklasifikasi, yaitu kewajiban keuangan yang ditetapkan demikian pada saat pengakuan awal dan kewajiban keuangan yang telah diklasifikasikan dalam kelompok diperdagangkan;

- Kewajiban keuangan lain

Figure 1. Classification of Financial Instruments of Bank BNI in 2010

Source: Bank BNI Financial Report 2010

In 2011 the classification of financial instruments in outline the same as in 2010 because based on information on the company's financial statements date of the revised 2006 new revised PSAK effective as of January 1, 2011. The company, in this case, has done the early application. In 2012 the information on classification is presented in more detail which includes classification of financial instruments and their definitions in accordance with the PSAK 55 revised 2011. This classification is conducted by the company up to the observation period of 2015.

\begin{tabular}{|c|c|c|c|}
\hline \multicolumn{2}{|c|}{$\begin{array}{c}\text { Kategori yang didefinis ikan } \\
\text { oleh PSAK } 55 \text { (Revisi 201 1)V } \\
\text { Categary as defined by SFAS } 55 \text { (Revised 2011) } \\
\end{array}$} & $\begin{array}{l}\text { Golongan } \\
\text { (ditentukan oleh Grup)V } \\
\text { Class } \\
\text { (as determined by the Group) }\end{array}$ & $\begin{array}{c}\text { Subgolongand } \\
\text { Subclasses }\end{array}$ \\
\hline \multirow{20}{*}{$\begin{array}{l}\text { Aset keuangan/ } \\
\text { Fnancial assets }\end{array}$} & \multirow{3}{*}{$\begin{array}{l}\text { Aset keuangan yang diukur } \\
\text { pada nilai wajar melaiui laba } \\
\text { tugil Firamoial assets at fair } \\
\text { value through profit } \alpha \text { loss }\end{array}$} & \multirow{3}{*}{$\begin{array}{l}\text { Aset keuangan daiam keiompok } \\
\text { diperdagangkan/Firamcial } \\
\text { assets hedd for trading }\end{array}$} & Elak-efakMMarkebable securibes \\
\hline & & & $\begin{array}{l}\text { Obigasi Pemedintah/ Government } \\
\text { Bonds }\end{array}$ \\
\hline & & & $\begin{array}{l}\text { Taghan derivatif - Tidak terkait } \\
\text { lindung nilai/ Derivative } \\
\text { receivables - Non heodging } \\
\text { relafed }\end{array}$ \\
\hline & \multirow{11}{*}{$\begin{array}{l}\text { Pinjaman yang dberikan dan } \\
\text { piutang/Loans and } \\
\text { eceivables }\end{array}$} & Kas/Cash & Kas pada vendow Cash in vendor \\
\hline & & \multicolumn{2}{|c|}{ Giro pada Bank Indonesia/Current accounts with Bank indonesia } \\
\hline & & \multicolumn{2}{|c|}{ Giro pada bark laiv Current accourts with cther banks } \\
\hline & & \multicolumn{2}{|c|}{$\begin{array}{l}\text { Penempatan pada bark lain dan Bank Indonesial Placements with other } \\
\text { banks and Bank indoresia }\end{array}$} \\
\hline & & \multicolumn{2}{|c|}{$\begin{array}{l}\text { Elek-efek yang dibeli dengan janj, d, wal kembai/Securifies punchased } \\
\text { under agreements to resel }\end{array}$} \\
\hline & & \multicolumn{2}{|c|}{ Wesel ekspor dan taghan lainmya/Bils and other receivables } \\
\hline & & \multicolumn{2}{|c|}{ Tagitran akseptasi/Acceptance receivables } \\
\hline & & \multicolumn{2}{|l|}{ Pinjaman yang dberikan/Loans } \\
\hline & & \multirow{3}{*}{ Aset lain-laiv Other assets } & Piutang lain-lain/Other neceivables \\
\hline & & & Piutang bungalinterest receivables \\
\hline & & & Lan-birVOthers \\
\hline & \multirow{2}{*}{$\begin{array}{l}\text { Aset keuangan dimi iki hingga } \\
\text { jatuh tempo/ Hedd-to-maturity } \\
\text { investments }\end{array}$} & \multicolumn{2}{|l|}{ Erek-efek/Manketable securities } \\
\hline & & \multicolumn{2}{|c|}{ Obigasi Perneintah Government Bonds } \\
\hline & \multirow{3}{*}{$\begin{array}{l}\text { Aset keuangan tersedia untuk } \\
\text { dfual/Availabk-for-sale } \\
\text { firancial assets }\end{array}$} & \multicolumn{2}{|l|}{ Erek-efekMarketable securities } \\
\hline & & \multicolumn{2}{|c|}{ Obigasi PernedintahVGoverrment Bonds } \\
\hline & & \multicolumn{2}{|c|}{ Penyedasn saham/Equity investmerts } \\
\hline & $\begin{array}{l}\text { Derivatif lindung nilai//tedging } \\
\text { denvivatives }\end{array}$ & $\begin{array}{l}\text { Lindung nilai atas nilai ans } \\
\text { kas/Hedging instruments in } \\
\text { cash flow hedges }\end{array}$ & $\begin{array}{l}\text { Taghan derivatif - Tedcait lindung } \\
\text { niai atas arus kas/Derivative } \\
\text { receivables - Hedging } \\
\text { instruments } h \text { cash flow hedges } \\
\text { redated }\end{array}$ \\
\hline
\end{tabular}

Figure 2. Classification of Financial Instruments of Bank BNI in 2013

Source: Bank BNI Financial Report 2013

The provisions of the reclassification of financial instruments at Bank BNI are in accordance with the development of the applicable PSAK. In 2009 it was revealed that the reclassification of financial instruments was not allowed except for certain 
things when in 2012 the regulation on reclassification was rather loose. Movement of classification of a financial instrument is permitted in case of change of management intensity and fulfill the applicable PSAK definition and regulation.

The process of determining the fair value of financial instruments in 2009 is based on the prevailing market price at the balance sheet date, if the market offer price does not exist then an estimate is based on the fair value of another instrument whose substance is the same or calculated based on the expected cash flows on the instrument. In 2010 the company explained that the determination of fair value is made at the quoted price in the active market, otherwise, no firm will make an estimate on the basis of credit spread. In 2012 added that in the process of determining the fair value of financial instruments the company uses two hierarchies as follows:

(i) Tingkat 1: dikutip (tidak dapat disesuaikan) dari harga pasar aktif untuk aset atau liabilitas keuangan yang identik,

(ii) Tingkat 2: teknik lain dimana semua input yang memiliki efek signifikan dalam pencatatan nilai wajar, dapat diobservasi baik secara langsung maupun tidak langsung;

Figure 3. Hierarchy of Fair Value Determination

Source: BNI Bank Financial Report for 2012

In 2013, the hierarchy of the determination of the fair value of financial instruments is detailed with the following stages:

- Level 1: Prices quoted (not adjusted) from active markets for identical financial assets or liabilities;

- Level 2: Inputs other than quoted prices from markets included in Level 1 that can be observed for financial assets and liabilities either directly (i.e. as a price) or indirectly (i.e. as a derivative of the price);

- Level 3: inputs for financial assets or liabilities that are not based on observable market data (unobservable information.

(Bank BNI Financial Report for 2013)

The disclosure of the fair value hierarchy by the company is then implemented in the financial reporting stage presented in Figure 4. 


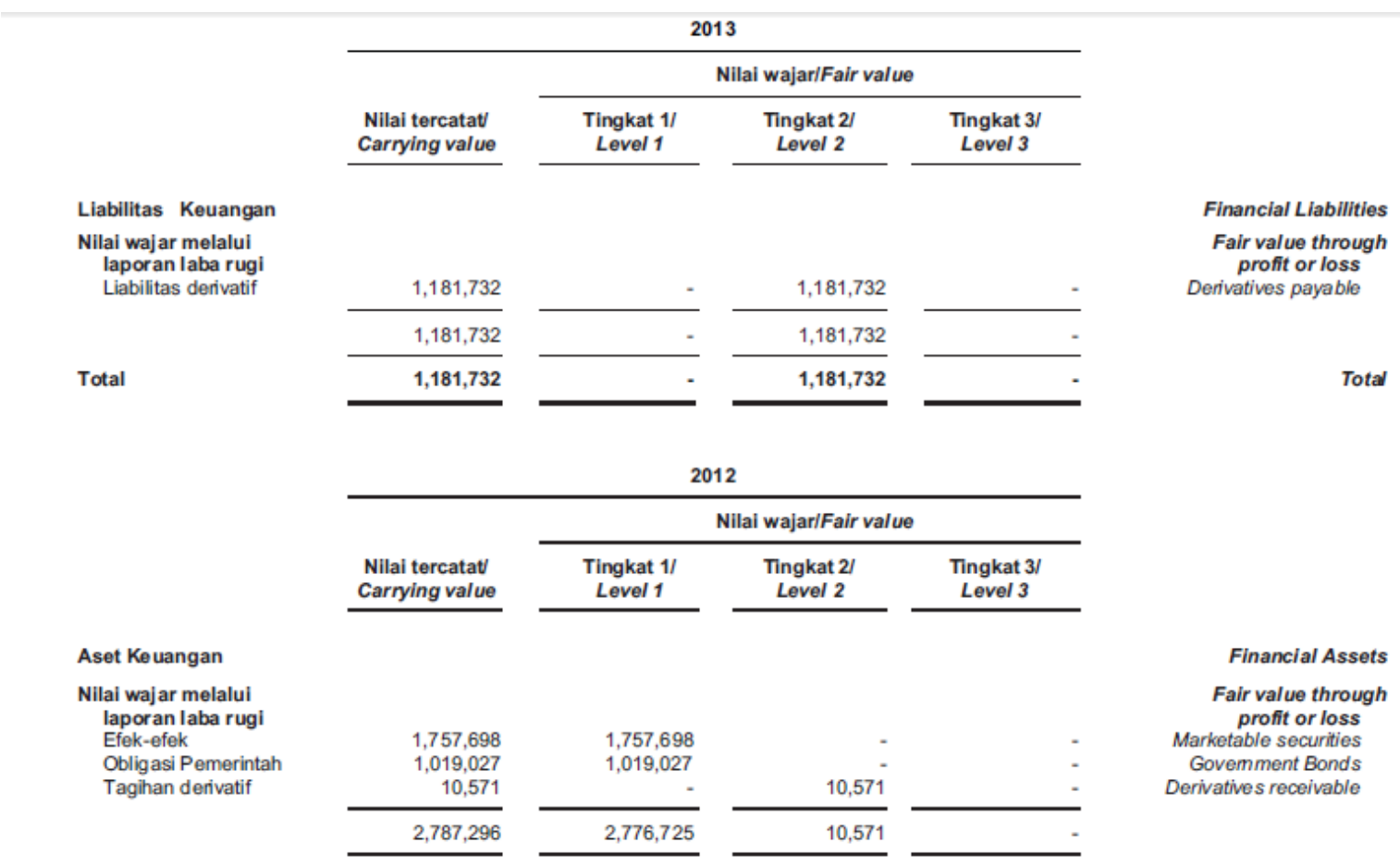

Figure 4. Presentation of Fair Value of Financial Instruments in the financial statements Source: BNI Bank Financial Report for 2013

PT. Bank Negara Indonesia (Persero) Tbk has implemented IFRS converged PSAK for financial instruments (PSAK 50, 55, and 60) in accordance with the adaptation stage. Even companies have volunteered to make early adoptions before the effective date is enacted. In the comparative analysis of financial statements presented from 2009 to 2015, it was found that the application of IFRS converged IFRS has a positive impact on users of financial statements because the information presented is complete and informative so that no mistakes in the economic decisionmaking process are expected.

It supports the implementation of IFRS convergence PSAK in the company is a gradual adaptation process so that the company can prepare the internal management condition to follow the existing development. In addition, prior to the effective enactment of a new PSAK has organized PPLs that invite company practitioners to establish a common perception of financial reporting importance in accordance with PSAK that refers to international standards. The regulatory provisions in PSAK 25 also support the implementation of changes that have been made by IAI towards global standardization, where companies are required to restate their financial statements in the event of regulatory changes before they are effectively established. This Regulation of PSAK 25 encourages companies to make initial implementation of changes in accounting standards applicable in Indonesia.

\section{CONCLUSION AND RECOMMENDATION}

Accounting standards in Indonesia are progressing continuously to meet the rapidly growing business needs. The decision to adopt the international accounting standards in full is a solution offered by the international business environment to improve the quality of financial statements and global benchmarks. Indonesia as a G20 member has committed to fully adapt international standards (IFRS) for the first phase of 2012 and 2015 to enter the second phase. 
Accounting regulations in Indonesia have been developed on an ongoing basis. This will certainly bring a certain impact for the industry in the country one of the banking industry. Banking is one of the unique sectors to be studied because its operational activities are very different than other sectors, becoming the main determinant of national economic liquidity and the number of binding regulations. The results of the analysis have shown that banking companies can implement changes in accounting standards quickly and in accordance with the rules of regulations that apply primarily to financial instruments. The Company has implemented IFRS converged PSAK for financial instruments (SFAS 50, 55, and 60) in accordance with the adaptation stage. Even companies have volunteered to make early adoptions before the effective date is enacted. However, this study only focuses on one banking company because of constrained research time so that the results cannot be generalized research. For further research can be developed by involving all banking companies in Indonesia.

What is interesting to examine on similar research in the future is the regulatory changes for financial instruments. PSAK 55 (revised 2014) and effective on January 1,2015 , has received much criticism among practitioners, so that 2017 is issued PSAK 71 which is planned to become effective as of January 1, 2020. PSAK 71 has a significant impact different from the regulation in PSAK 55

\section{REFERENCES}

Antunes, P. L dan Moore, J. 2013. CASE STUDY The Implementation of IAS 16 and IAS 41 at Andrew Peller Limited. Accounting Education: an international journal. Vol. 22 (3): 268-281

Balev, B dan Hadad, J.R. 2007. Harmonization, Comparability, and Fair Value Accounting. Journal of Accounting, Auditing, and Finance. Vol. 22(3): 493509.

Balsari, C. K., Serdar Ozkan, dan Gurol Durak. (2010). Earnings Conservatism In Pre- And Post IFRS Periods In Turkey : Panel Data Evidence ON The Firm Spesific Factors. Accounting and Management Information Systems Vol. 9(3): 403-421

Budiarti, A. E. dan Sularto, L. Implementasi PSAK 50 Dan 55 Sebelum Dan Sesudah Konvergensi Penerapan IFRS las 32 Dan 39 Serta Dampaknya Terhadap Laba Dan Harga Saham Pada Industri Perbankan. Proceeding PESAT (Psikologi, Ekonomi, Sastra, Arsitektur \& Teknik Sipil). Vol. 5: 203-208.

Choi, Frederick D.S dan Gary K. Meek. 2008. International Accounting Sixth Edition. Pearson Prentice Hall.

Chua, Yie Lin, Chee Seng Cheong dan Graeme Gould. 2012. The Impact of Mandatory IFRS Adoption on Accounting Quality: Evidence from Australia. Journal of International Accounting Research11(1):119-146

Dewi, N.H.U, Almilia, L.S, dan Herlina, E. 2012. Akuntansi Keuangan Menengah Vol.1: Pendekatan SAK, SAK ETAP, dan IFRS Dilengkapi Soal Latihan. STIE Perbanas Press. Surabaya.

Doupnik, T., Hector Perera. (2007). International Accounting, Mc Graw Hill Book, New York.

Emzir. (2010). Metodologi Penelitian Kualitatif: Analisis Data. Jakarta: Raja Grafindo. Epstein dan Jermakowicz. 2010. Interpretation and Application of IFRS. John and Willey Sons.

Febriati, E.C. 2013. Analisis Penerapan PSAK 55 Atas Cadangan Kerugian Penurunan Nilai. Jurnal EMBA. Vol.1 (3) : 207-217. 
Handoko. 2010. Nilai Wajar (Fair Value). https://rogonyowosukmo.wordpress.com/2010/11/24/nilai-wajar/ diakses pada $\operatorname{tgl}$ 28/052016 pukul 14:06

Hardiani, Indri. 2014. Fair value measurement: masalah baru atau solusi pada pelaporan keuangan (studi fenomenologi atas pandangan auditor). Skripsi. Universitas Diponergoro : Semarang

IAI. 2007. Pernyataan Standar Akuntansi Keuangan. Salemba Empat. Jakarta

IAI. 2015. Standar Akuntansi Keuangan. Salemba Empat Jakarta

IAI. 2017. Standar Akuntansi Keuangan. Salemba Empat Jakarta

Larasati, A dan Supatmi. 2014. Pengungkapan Informasi Aset Keuangan Dan Impairment-Nya Di Perbankan Menurut PSAK 50 dan 60.Seminar Nasional dan Call for Paper (Sancall 2014): 296-306

Landsman, W.R. 2006. Fair Value Accounting for Financial Instruments: Some Implications for Bank Regulation. BIS Working Papers. No 209: 1-22

Oliveira, J., Rodrigues, L.L dan Craig, R. 2011. Risk-related disclosure practices in the annual reports of Portuguese credit institutions: An exploratory study. Journal of Banking Regulation Vol. 12 (2): 100-118

Peng, S dan Bewly, K. 2010. Adaptability to Fair Value Accounting in an Emerging Economy; A Case Study of China's IFRS Convergence. Accounting, Auditing and AccountabilityJournal. Vol. 23(8): 982-1011

Penman, S.H. 2007. Fiancial Reporting Quality: Is Fair Value a Plus or a Minus?. Accounting and Business Research. Vol 37 (3) : 22-44

Pulumbara, D.C., Sondakh, J.J dan Wangkar, A. 2014. Analisis Penerapan PSAK 50: Penyajian dan PSAK 55: Pengakuan dan Pengukuran Atas Cadangan Kerugian Penurunan Nilai Pada PT. BANK CENTRAL ASIA (PERSERO) Tbk. Jurnal EMBA Vol 2 (3): 1350-1358.

Sukendar. H. 2012. Konsep Nilai Wajar (Fair Value) Dalam Standar Akuntansi Berbasis IFRS di Indonesia Apa dan Bagaimana?. Binus Business Review. Vol. 3 (1) : 93-106

Wardhani, R. (2009). Pengaruh Proteksi Bagi Investor, Konvergensi Standar Akuntansi, Implementasi Corporate Governance, Dan Kualitas Audit Terhadap Kualitas Laba: Analisis Lintas Negara Di Asia, Disertasi, Program Pasca Sarjana Universitas Indonesia, Jakarta.

Wibisana, M.J. 2009. Dengan Fair Value, Lporan Keuangan Lebih Transparan. Buletin Akuntan Indonesia. Vol. 16 : 22-25.

Yusuf. H. 2009. Jujur Kita Belum Siap dengan Fair Value. Buletin Akuntan Indonesia. Vol. $16: 26-30$. 